\title{
管内マルチ噴流の混合特性に及ぼす旋回と浮力の効果*
}

\author{
田中美也子*1, \\ 巽 和 也*2 \\ Peter L. WOODFIELD*3, 中 部 主 敬*2
}

\section{Swirl and Buoyancy Effects on Mixing Performance of a Confined Multiple Jet}

\author{
Miyako TANAKA, Kazuya TATSUMI, \\ Peter L. WOODFIELD and Kazuyoshi NAKABE*4 \\ ${ }^{* 4}$ Department of Mechanical Engineering. Osaka Prefecture University, \\ 2-1 Gakuen-cho, Sakai-shi, Osaka, 599-8531 Japan
}

\begin{abstract}
Effects of swirl motion and buoyancy force on the mixing performance of a confined multiple jet mounted flush with a baffle plate in a small chamber were numerically investigated under laminar flow conditions. The swirl motion was induced by circumferentially-inclined jets surrounding the central jet. The buoyancy force was applied to the multiple jet by changing the operating direction of the gravity against the axis of the chamber. In the swirl flow cases, the reverse flow formed downstream of the baffle plate was restrained gradually with an increase in swirl number, which incurs the deterioration of the mixing performance in comparison to the non-swirl case. In the buoyancy-accompanied flow cases, asymmetric angle between the directions of the gravity force and the central jet led to poor mixing performance. This trend was more noticeable in the compound flow case of the swirl motion and the buoyancy force.
\end{abstract}

Key Words: Confined Multiple Jet, Mixing Effect, Swirl Flow, Buoyancy Force, Laminar Flow, Numerical Simulation

\section{1. 緒言}

流体どうしの混合は反応容器内での試薬混合や燃焼 器内での燃料一空気混合, 空調設備などにおける高温 流体一低温流体混合など, 様々な熱流体機器や工業プ ラントにおいて頻繁に見られる現象である。そこでは 機器の高効率化や省スペース化などを達成するため, 短い距離で迅速に十分な混合を可能にする制御技術が 要求される. とくに近年のコンパクト化, マイクロ化 の技術開発に関連して極少量の流体供給で充足するよ うな場合には, 流れが層流域に留まって一般的な乱流 混合を行うことができないため, 流路設計には混合促 進を施すための工夫が必須となる.

そこで本研究では具体例として, 著者の一人が以前, 燃焼実験を行った小寸法管内マルチ噴流 (1) を対象に, その流動特性が旋回の強さおよび浮力の作用によって

\footnotetext{
* 原稿受付 2006 年 1 月 19 日.

*1 学生員, 大阪府立大学大学院工学研究科( $599-8531$ 堺市 学園町 1-1).

*2 正員, 大阪府立大学大学院工学研究科.

*3 佐賀大学海洋エネルギー研究センター(画 849-4256 伊万里 市山代町久原 1-48).

E-mail : nakabe@ me.osakafu-u.ac.jp
}

受ける影響を数値的に予測し，検討する.ここで管内 マルチ噴流は図 1(a) に示すような, 燃料ノズルおよび その周囲を取り囲む複数の空気噴孔を有するバッフル 板を通して円管内に吹き込まれる噴流の呼称である. また，その流動特性として，単純な管内同軸噴流に比 して二流体混合の性能に秀で, 火炎長が短く, 当量比 の広い範囲にわたって安定した火炎が形成できること が文献 (1) に示されている. Woodfield ら (2) は三次 元数值シミュレーションを行い，同噴流の良好な混合 性能には, 周囲の空気噴流が中心部の遅い燃料噴流を 巻き込むようにして形成する大規模な逆流およびバッ フル板に沿う強い半径方向外向き流れの寄与が大きい ことを明らかにした．一方，バッフル板上流の流動状 態, 例えば配管流路に沿った速度分布の偏りなどが下 流側の噴流挙動に及ぼす影響については, バッフル板 の効果によって軽減されることも明らかにした ${ }^{(3)}$.

$$
\text { ここでは図 1(b) ならびに (c) にそれぞれ示すよう }
$$

に, 流体がバッフル板を通過する際に旋回成分を噴流 に付与する場合ならびに噴流間の温度差のために浮力 


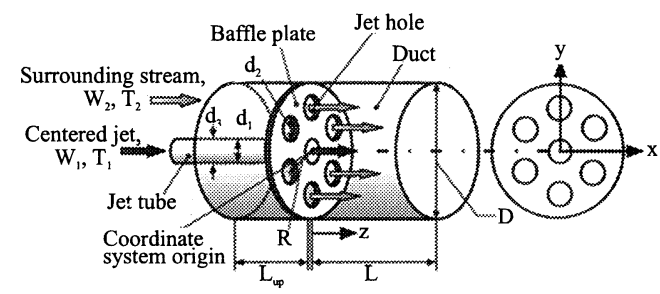

(a) A confined multiple jet
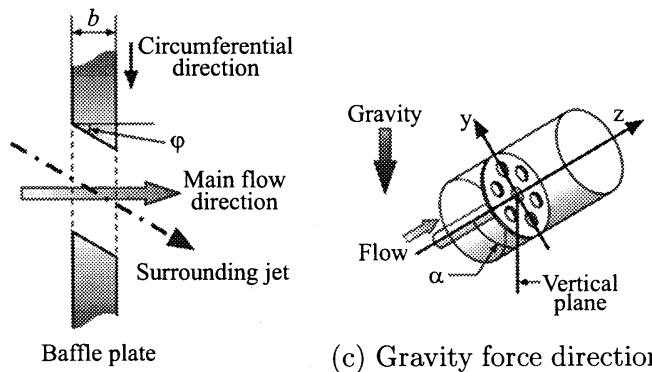

(c) Gravity force direction

(b) The inclined angle of surrounding jet

Fig. 1 Geometrical configuration.

が作用する場合を想定し，それらによって管内マルチ 噴流の混合性能がどのような変化を受けるかについて 数値的検討を行うことにした.

\section{2. 記号}

$b \quad$ バッフル板厚さ $[\mathrm{m}]$

$C t$ クラヤーカーテー数

$D$ 円管直径 $[\mathrm{m}]$

$d_{1} \quad$ 中心噴流管内径 $[\mathrm{m}]$

$d_{2}$ 周囲噴流噴孔直径 $[\mathrm{m}]$

$d_{3}$ 中心噴流管外径 $[\mathrm{m}]$

$g$ 重力加速度 $\left[\mathrm{m} / \mathrm{s}^{2}\right]$

$G_{a}$ 角運動量流量 $\left[\mathrm{kgm}^{2} / \mathrm{s}^{2}\right]$

$G_{t} \quad$ 並進運動量流量 $\left[\mathrm{kgm} / \mathrm{s}^{2}\right]$

$G r \quad$ グラスホフ数 $\left(=g \beta\left(T_{1}-T_{2}\right) D^{3} / \nu_{m}^{2}\right)$

$h \quad$ 比エンタルピ $[\mathrm{J} / \mathrm{kg}]$

$L \quad$ バッフル板下流の円管長さ $[\mathrm{m}]$

$L_{u p} \quad$ バッフル板上流の円管長さ $[\mathrm{m}]$

$m_{1}$ 中心噴流の質量流量 $[\mathrm{kg} / \mathrm{s}]$

$m_{2}$ 周囲噴流の質量流量 $[\mathrm{kg} / \mathrm{s}]$

$P \quad$ 中心噴流管入口基準の相対圧力 $[\mathrm{Pa}]$

$p$ 圧力 $[\mathrm{Pa}]$

$p_{0} \quad$ 中心噴流管入口における静圧 $[\mathrm{Pa}]$

$P r \quad$ プラントル数

$R$ 円管中心軸と周囲噴流噴孔中心間の距離 $[\mathrm{m}]$ $r$ 円管中心軸からの距離 $[\mathrm{m}]$

$R e$ レイノルズ数 $\left(=W_{m} D / \nu_{m}\right)$

$R i$ リチャードソン数 $\left(=G r / R e^{2}\right)$

Sc シュミット数

$S w$ スワール数

$T_{1} \quad$ 中心噴流の温度 $[\mathrm{K}]$

$T_{2}$ 周囲噴流の温度 $[\mathrm{K}]$

$u_{i} \quad$ カーテシアン座標における速度成分 $[\mathrm{m} / \mathrm{s}]$ $(=u, v, w ; i=1,2,3)$

$u_{\theta} \quad$ 周方向旋回速度 $[\mathrm{m} / \mathrm{s}]$ $\left(=\left(v^{2}+w^{2}\right)^{0.5}\right)$

$W_{d} \quad C t$ の定義に用いる余剩スラスト生成の平均 流速 $[\mathrm{m} / \mathrm{s}]$

$W_{f} \quad C t$ の定義に用いる周囲流平均流速 $[\mathrm{m} / \mathrm{s}]$

$W_{m} \quad$ バッフル板下流側端面での平均流速 $[\mathrm{m} / \mathrm{s}]$

$W_{1} \quad$ 中心噴流管出口の断面平均流速 $[\mathrm{m} / \mathrm{s}]$

$W_{2}$ 周囲噴流噴孔出口の断面平均流速 $[\mathrm{m} / \mathrm{s}]$

$x_{i} \quad$ カーテシアン座標 $[\mathrm{m}]$

$(=x, y, z ; i=1,2,3)$

$\alpha$ 鉛直上向きを基準に，系全体を $x$ 軸周りに回 転させた時の回転角 $\left[{ }^{\circ}\right]$

$\beta \quad$ 体膨張係数 $[1 / \mathrm{K}]$

$\varphi \quad$ 周囲噴流噴孔傾斜角 $\left[{ }^{\circ}\right]$

$\mu \quad$ 粘性係数 [Pas]

$\nu \quad$ 動粘性係数 $\left[\mathrm{m}^{2} / \mathrm{s}\right]$

$\nu_{m} \quad$ バッフル板下流側端面での平均温度における 動粘性係数 $\left[\mathrm{m}^{2} / \mathrm{s}\right]$

$\rho_{1} \quad$ 中心噴流の密度 $\left[\mathrm{kg} / \mathrm{m}^{3}\right]$

$\rho_{2} \quad$ 周囲噴流の密度 $\left[\mathrm{kg} / \mathrm{m}^{3}\right]$

$\xi$ 中心噴流流体の質量分率

\section{3. 計 算 手 法}

管内マルチ噴流系の三次元定常層流数值解析に用い た支配方程式を以下に示す. 式 (1)〜(4) はそれぞれ， 連続の式, 運動量保存式, エネルギー保存式および混 合質量分率 $\xi$ の保存式を表す.

$$
\begin{aligned}
\frac{\partial u_{i}}{\partial x_{i}} & =0 \\
\rho \frac{\partial}{\partial x_{j}}\left(u_{i} u_{j}\right) & =-\frac{\partial p}{\partial x_{i}}+\frac{\partial}{\partial x_{j}}\left(\mu \frac{\partial u_{i}}{\partial x_{j}}\right) \\
\rho \frac{\partial}{\partial x_{j}}\left(u_{j} h\right) & =\frac{\partial}{\partial x_{j}}\left(\frac{\mu}{\operatorname{Pr}} \frac{\partial h}{\partial x_{j}}\right) \\
\rho \frac{\partial}{\partial x_{j}}\left(u_{j} \xi\right) & =\frac{\partial}{\partial x_{j}}\left(\frac{\mu}{S c} \frac{\partial \xi}{\partial x_{j}}\right)
\end{aligned}
$$

ただし， $\xi$ は中心噴流管から供給される流体の質量分 率であり， $\xi=1$ はその位置において中心噴流流体が $100 \%$ を占め, $\xi=0$ は周囲噴流流体が $100 \%$ を占め 
ることを意味する．また， $h$ は流体の持つ比エンタル ピである. $P r$ および $S c$ はそれぞれ，プラントル数お よびシュミット数であり, $P r=0.7, S c=0.7$ とし た. 浮力を考慮する場合については, 周囲噴流流体温 度を基準に取ったブジネスク近似を運動量保存式に施 して計算を行った。

支配方程式の離散化には図 1 のような複雑な流路系 を扱うので, 図 2 に示すような非構造格子（総格子点 数は約 $7.2 \times 10^{5}$ 点）に基づいた三次元有限体積法を 採用した ${ }^{(4)}$. 対流項には二次精度風上差分を, 拡散 項には二次精度中心差分を用いた。 また，集中格子を 用いていることから，圧力の不連続性を回避するため に, Rhie と Chow の手法 ${ }^{(5)}$ を適用した. 圧力補正は SIMPLE を適用し, 繰り返し法としてヤコビ法を採 用した。 なお，計算時間は沉用計算機（Intel 製 P4 搭 載）でおよそ 48 時間を要した.

計算条件を表 1 に示す. 表中の条件名称として, Case-C は管内同軸噴流の場合, Case-B は管内マルチ 噴流の場合を表す。また, Case-S20 および Case-S40 は周囲噴流噴孔の傾斜角 $\varphi$ をそれぞれ， $20^{\circ}$ および $40^{\circ}$ にとった旋回の伴う管内マルチ噴流の場合を表す．ま た，これらの条件名称の次に続く記号 ' $\mathrm{b}$ ' は浮力を考 慮した場合であることを意味し，その後に続く数字は 浮力の作用方向を表寸角度 $\alpha$ の值を指寸. なお, 旋回 を伴う'S20'ならびに 'S40' の場合には, 周囲噴流に 十分な旋回成分を付与するため, 噴孔の傾斜長さをあ る程度長くとれるよう, 無次元バッフル板厚さ $b / D$ を 5 倍にした。 その影響を調べるため, 旋回の伴わない Case-B の場合についても $b / D$ を 5 倍に変更した比較 計算を行ったが, 変更の前後で流動特性に大きな違い は見られなかった。

ガス組成は中心噴流, 周囲噴流ともに純窒素と仮 定し, バッフル板出口端面における両者の質量流量比 $m_{1} / m_{2}$ は 0.0488 に固定した.この值は文献 (1)の燃 焼実験に対応させるべく文献 (2) においても採用した 值であり,メタン一空気当量比に換算して量論混合状 態よりやや希薄な值である約 0.84 に相当する．また， 端面における平均流速基準のレイノルズ数 Reを, 速 度場が脈動や非軸対称化を起こさない範囲内で，100 に固定し, 浮力の効果についてはリチャードソン数 $R i$ を6.85一定とした。

\section{4. 計算結果および考察}

$4 \cdot 1$ 同軸噴流とマルチ噴流の比較図 3 および 図 4 に, 速度ベクトルと混合質量分率 $\xi$ を併記した 縦断面（ $x / D=0$ を含む $y-z$ 断面）内分布および横

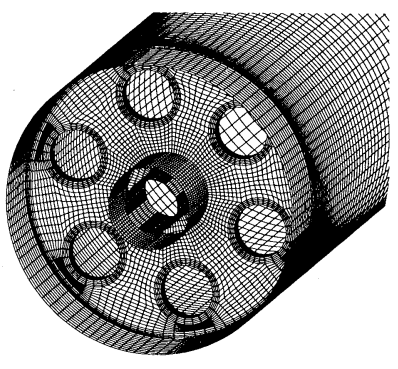

Fig. 2 Computational domain.

Table 1 Computational conditions.

\begin{tabular}{|c|c|c|c|c|c|c|c|}
\hline$d_{1} / D$ & $d_{2} / D$ & $d_{3} / D$ & \multicolumn{2}{|c|}{$R / D$} & $\overline{L_{u p} / D}$ & $\bar{L} / \bar{D}$ & $m_{1} / m_{2}$ \\
\hline 0.182 & 0.182 & 0.28 & & & 1 & 15 & 0.0488 \\
\hline \multicolumn{3}{|c|}{ Case } & $b / D$ & $\begin{array}{c}\varphi \\
{\left[{ }^{\circ}\right]}\end{array}$ & $\begin{array}{l}T_{1} \\
{[\mathrm{~K}]}\end{array}$ & $\begin{array}{c}T_{2} \\
{[\mathrm{~K}]}\end{array}$ & $\begin{array}{c}\alpha \\
{\left[{ }^{\circ}\right]}\end{array}$ \\
\hline \multicolumn{3}{|c|}{ Case-C } & - & - & 300 & 300 & - \\
\hline \multicolumn{3}{|c|}{ Case-B } & 0.05 & 0 & 300 & 300 & - \\
\hline \multicolumn{3}{|c|}{ Case-S20 } & 0.25 & 20 & 300 & 300 & - \\
\hline \multicolumn{3}{|c|}{ Case-S40 } & 0.25 & 40 & 300 & 300 & - \\
\hline \multicolumn{3}{|c|}{ Case-Bb0 } & 0.05 & 0 & 350 & 300 & 0 \\
\hline \multicolumn{3}{|c|}{ Case-Bb90 } & 0.05 & 0 & 350 & 300 & 90 \\
\hline \multicolumn{3}{|c|}{ Case-Bb180 } & 0.05 & 0 & 350 & 300 & 180 \\
\hline \multicolumn{3}{|c|}{ Case-S20b0 } & 0.25 & 20 & 350 & 300 & 0 \\
\hline \multicolumn{3}{|c|}{ Case-S20b90 } & 0.25 & 20 & 350 & 300 & 90 \\
\hline \multicolumn{3}{|c|}{ Case-S20b180 } & 0.25 & 20 & 350 & 300 & 180 \\
\hline
\end{tabular}

断面（ $z / D=0.1$ を含む $x-y$ 面）内分布を，それぞ れ示す. 両図中の (a)〜 (d) はそれぞれ, 同軸噴流の 場合 (Case-C)，マルチ噴流の場合 (Case-B), $S w$ 数の異なる旋回を伴う二つの場合（Case-S20 および Case-S40) である.

本節ではマルチ噴流に及ぼす旋回および浮力の効果 を論じる前に, 図 3 , 図 4 それぞれの，(a) 従来型管内 同軸噴流と (b) バッフル板挿入型管内マルチ噴流にお ける混合特性の比較を行う. 両者を比較すると, 中心 噴流管から供給される流体と周囲噴流噴孔から供給さ れる流体が半径方向にあまり広がることなく下流方向 へと流れ去る前者 (a) の場合に対して, 後者 (b) の場 合にはバッフル板端面近傍の $z / D=0 \sim 0.15$ 付近に $\xi$ の等值線が集中していること, また, 中心噴流管か らの流体が管側壁周辺にまで輸送されていることが, 繸・横断面内分布図から明瞭に判別できる.

このことからマルチ噴流は同軸噴流に比べて，より 短い距離において混合を促進させることが分かる. 管 内マルチ噴流では, 前述のとおり燃焼実験の条件に対 応して周囲噴流流速を中心噴流流速よりも相対的に大 きく設定しているので，管中心部に大きな逆流領域が 形成される ${ }^{(2)}$. それに随伴して, バッフル板近傍に 管中心部から管側壁に向かう強い半径方向外向き流れ が生じている．このような流動構造がマルチ噴流の流 体混合を促進する要因になっていると考えられる. 


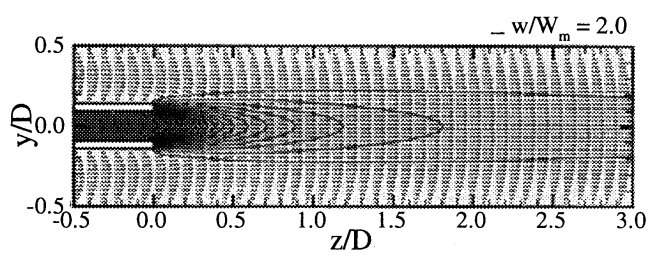

(a) Case-C

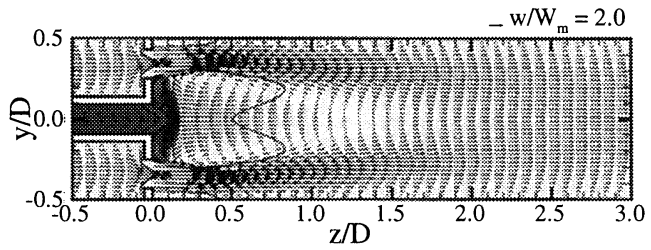

(b) Case-B

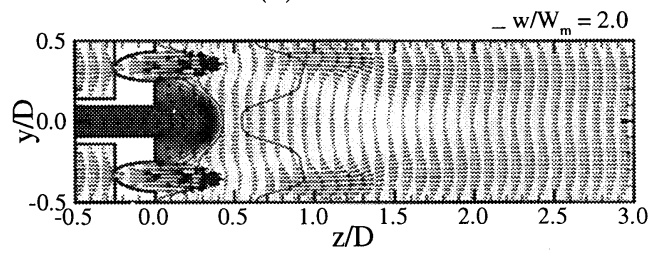

(c) Case-S20

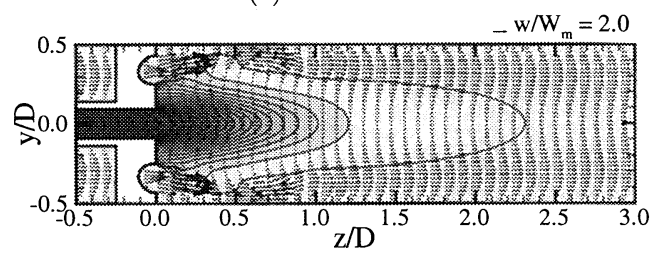

(d) Case-S40

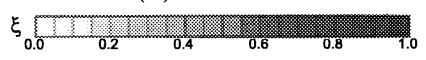

Fig. 3 Mixture fraction contours, $\xi$, and velocity vectors at the $y-z$ cross section of $x / D=0$.

$4 \cdot 2$ 旋回が混合特性に及ぼす影響 前出の図 3 および図 4 の (c), (d) が旋回を伴うマルチ噴流の場合 に該当する. 本研究では旋回強度を表すパラメータと して，以下に定義するスワール数 $S w$ を用いた.

$$
S w \equiv \frac{G_{a}}{G_{t}(D / 2)}
$$

ただし，

$$
\left\{\begin{array}{l}
G_{a}=\int_{0}^{D / 2} \rho w r u_{\theta} \cdot 2 \pi r d r \\
G_{t}=\int_{0}^{D / 2}\left(\rho w^{2}+p_{0}\right) \cdot 2 \pi r d r
\end{array}\right.
$$

式 (5) を用いると, バッフル板出口端面 $(z / D=0.0)$ において, $S w$ 数はそれぞれ, (c) の噴孔傾斜角 $\alpha=20^{\circ}$ の場合（Case-S20）に0.20, (d) の $\alpha=40^{\circ}$ の場合 (Case-S40) に 0.39 となる.

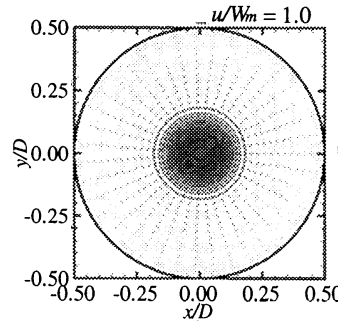

(a) Case-C

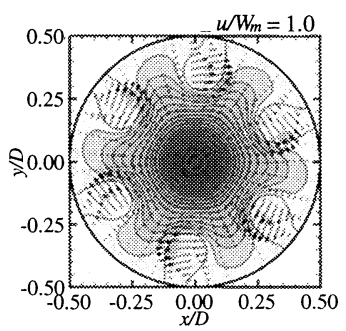

(c) Case-S20

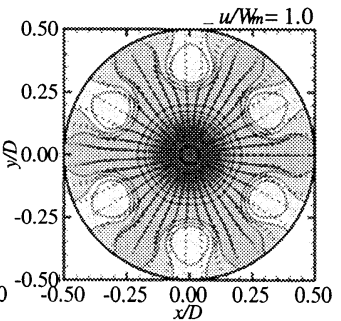

(b) Case-B

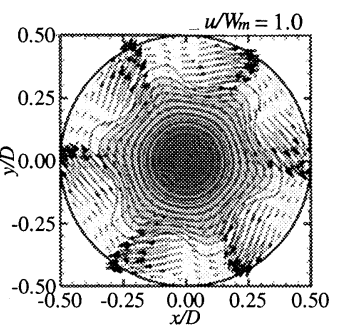

(d) Case-S40

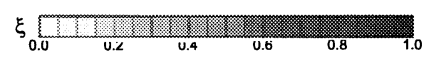

Fig. 4 Mixture fraction contours, $\xi$, and velocity vectors at the $x-y$ cross section of $z / D=$ 0.1 .

旋回のある場合を (b) の Case-B と比較すると, 後 者は前節で述べたとおり, $z / D=0 \sim 0.15$ 付近に $\xi$ の 等值線が集中し, $z / D=0.85$ 付近から下流での分布 がほぼ一様になっている. 具体的には $z / D=0.85$ 付 近の管中央部に描かれている曲線が $\xi=0.055$ の等値 線で, その線より下流側でメタン一空気混合気に換算 して量論混合比（質量流量比にして 0.058）以下の希 薄状態が実現している. 一方，旋回を伴う前者につい ては (c) の Case-S20 の場合に $z / D=1.0$ 付近, (d) の Case-S40 の場合に $z / D=2.3$ 付近より下流でよう やく $\xi \sim 0.055$ 程度になっており, 半径方向への広が り方も前者に比べて緩慢であることが分かる．また， 速度ベクトルの方向に注目すると, マルチ噴流の場合 には $S w$ 数が大きくなるほど, 逆流の程度が弱まると ともにその領域が下流へ移動しているように見える。 なお，以下の式 (7) に定義した循環流の有無の指標と されるクラヤーカーテー数 $C t^{(6)}$ を本条件に適用する と，管内同軸噴流 (Case-C) の場合，その值は約 2.0 となり, 循環流が形成されない範疇に入る. 一方, 残 りの 3 条件に対しては $C t$ 数がいずれも 0.48 程度とな $\eta$, 循環流形成の範疇 $(C t<3 / 4)$ に入る ${ }^{(6)}$. しか し, この值では, 形成される循環流の規模に対する旋 回の効果を直接的には反映していないことが分かる. 

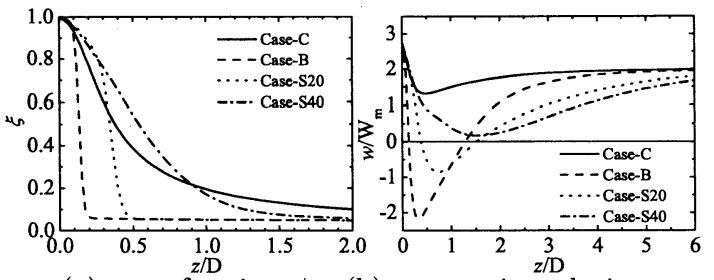

(a) mass fraction, $\xi$

(b) streamwise velocity, $w$

Fig. 5 Distributions of mixture fraction, $\xi$, and streamwise velocity, $w$, along the central axis of chamber.

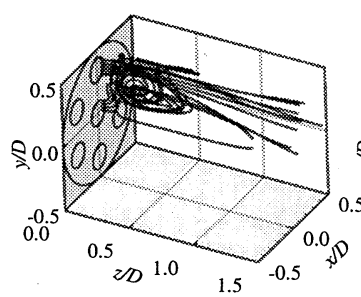

(a) Case-B

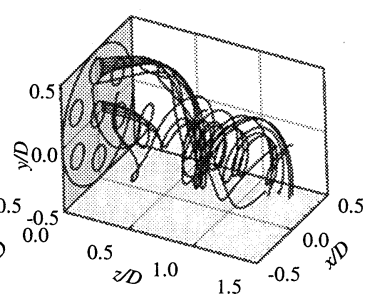

(b) Case-S40
Fig. 6 Path lines starting from the jet holes, on $x / D=0.05$ at the cross-section of $z / D=0$.

$$
C t \equiv \frac{W_{m}}{\sqrt{W_{d}^{2}-0.5 W_{m}^{2}}}
$$

ただし， $A_{0}, A_{1}$ および $A_{2}$ をそれぞれ，円管，中 心噴流管および周囲噴流噴孔の断面積として,

$$
\left\{\begin{array}{l}
W_{m}=\frac{1}{A_{0}} \int_{A_{0}} w d A \\
W_{d}^{2}=\frac{1}{A_{1}} \int_{A_{1}}\left(w^{2}-0.5 W_{f}^{2}\right) d A \\
W_{f}=\frac{1}{A_{2}} \int_{A_{2}} w d A
\end{array}\right.
$$

ここで，管中心軸に沿う $\xi$ ならびに主流方向速度 $w$ の変化を上述の 4 条件で比較した. 図 5 にその結果 を示す. 図中 (a) の破線で示された Case-B の場合を 他の場合と比較すると, $\xi$ は $z / D \sim 0.2$ 以降で約 0.1 にまで急減し, $z / D \sim 0.5$ 以降で前述の量論混合状態 $\xi=0.055$ にほぼ落ち着き, マルチ噴流の混合促進効 果をよく示している. 一方, 旋回を伴う Case-S20（点 線) および Case-S40 (一点鎖線) の場合には, $S w$ 数が 大きいほど, $\xi \sim 0.1$ 程度に急減する位置が下流側に移 動しており，その位置はそれぞれ，およそ $z / D \sim 0.45$ および 1.3 である. 同軸噴流である Case-C (実線) の 場合には $\xi$ の変化が緩慢で, $z / D=2.0$ の位置におい
てもなお漸減傾向が続き, 他の場合に比して $\xi$ の値は 大きい. しかし，図を注意深く眺めると，Case-Cの 場合は旋回を伴う Case-S20 および Case-S40 の場合 に比較して，それぞれ， $z / D \sim 0.32$ および 0.88 より 上流側において相対的に小さな $\xi$ の值を示しており， $S w$ 数の大きさに応じて混合が局所的に遅れることが 分かる. すなわち, その領域では $S w$ 数を増すほどに 管中心部の混合が抑制されることになる.

同図 (b) の管中心軸上における，規格化された主流 方向の時間平均速度 $w / W_{m}$ の変化を見ると, Case-B (破線) および Case-S20 (点線) の場合は $w$ が負值と なる領域，すなわち逆流領域を持つことが分かる。ま た，旋回を伴う後者の場合の方がその領域は下流側に 移動し，かつ，狭くなっていることが分かる. $S w$ 数 のさらに大きな Case-S40 (一点鎖線) の場合には, そ の領域が消滅している. ゆえに, $S w$ 数が増すほどに 逆流領域が下流側に移動し，その規模が縮小して混合 状態が悪化することになる．したがって，以上の結果 は $S w$ 数の増減, すなわちここでは周囲噴流噴孔の傾 斜角調整を行うことによって，管内マルチ噴流中心部 の混合が制御可能であることを示唆している.

つぎに, バッフル板近傍における混合状態に及ぼす 旋回の効果をより詳細に調べるため, Case-B および Case-S40 の場合について, 中心噴流および周囲噴流の 流跡線を時間間隔 $0.1 \mathrm{~ms}$ でプロットした. 図 6 にその 鳥甦図を示す．旋回を伴わない Case-B（同図 (a)）の 場合, これまでに述べたとおり, 中心噴流がバッフル 板出口直後で半径方向に広がり, 逆流領域を形成する ことが見て取れる. 一方, Case-S40（同図 (b)）の場 合には周囲噴流に随伴する旋回流れの影響を受けて, 比較的下流の管中央部で混合の進むことが分かる.

このような旋回成分の混合特性に及ぼす影響をさら に考察するため，管内の断面圧力分布を調べた. 図 7 はその結果で, $z / D=0.25$ の横断面における中心噴流 管入口の圧力を基準とする相対圧力 $P$ の分布ならびに 速度ベクトルの分布を示している. 旋回を伴う CaseS40（同図 (b)）の場合に見られる管側壁近傍の周方向 に周期的な圧力の高い領域は旋回を伴わない Case-B （同図 (a)）の場合には確認されず，これは 6 本の周囲 噴流が管側壁に衝突する際に形成される淀み領域に対 応するものと考えられる.この結果, 管中心部の流体 はその領域を迁回するように流れて半径方向外側へは 広がりにくくなり，したがって，管側壁近傍では周囲 噴流と十分に合流できずに，管中心部の逆流の規模も 縮小して混合状態が悪化すると考えられる.

バッフル板近傍の流動と混合状態を詳細に見るため 


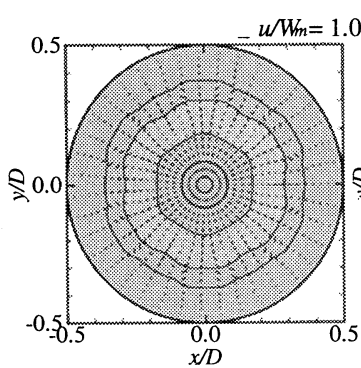

(a) Case-B

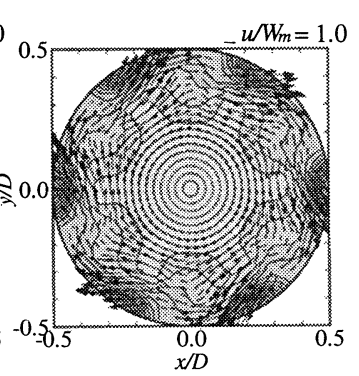

(b) Case-S40

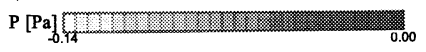

Fig. 7 Relative pressure contours, $P$, and velocity vectors at the $x-y$ cross section of $z / D=$ 0.25 .

に，図 3(a)〜 (d) に示した 4 つ分布図における $0<$ $y / D<0.5$ かつ $0<z / D<1.0$ の範囲を拡大して図 8 に示す. これを見ると $(\mathrm{b}) \sim(\mathrm{d})$ にはいずれも時計回 りの渦の存在が確認できるが, バッフル板端面近傍の 中心噴流と周囲噴流の間の $\xi$ が比較的大きな值を取る 領域に, 反時計回りの渦も確認できる. しかも, $S w$ 数が大きいほど, その渦の規模は大きい. したがって, 前述のことと考え合わせると， $S w$ 数を大きくして例 えば燃料一空気の混合制御を行う場合, この渦領域が 過濃混合気を保持して保炎の役割を担うことができる と考えられ，旋回による火炎安定制御への応用に繋が る結果と言える.

$4 \cdot 3$ 浮力が混合特性に及ぼす影響図 9 に, 浮 力を考慮した場合のマルチ噴流について，質量分率 $\xi$ および速度べクトルの断面分布図を示す. 断面の位置 は図 3 の場合と同じである. 同図 (a) の Case-Bb0 およ び (c) の Case-Bb180における浮力の作用する方向は ともに主流方向と平行であり，前者は主流と同じ方向 (順方向), 後者は主流に逆らう方向（逆方向）である. これら二つの場合と浮力を考慮しない場合（Case-B， 図 3(b) 参照) を比較すると， $\xi$ の分布パターンについ ては管中心部の窪み形状に若干の差こそ見られるもの の，類似している. また，速度べクトル分布について も大差ないことから，いずれの場合も混合特性がほぼ 同じであると判断でき.る.

一方, 浮力の向きが主流方向に対して直交する CaseBb90 の場合（図 9(b)）については， $\xi$ の分布に非軸 対称性が見られる.これはやはり浮力の作用方向が主 流方向と平行でないことから, 中心噴流から供給され る比較的高温の流体が浮力の作用方向に沿って偏って 流動するためと考えられる. その結果として， $\xi$ の分

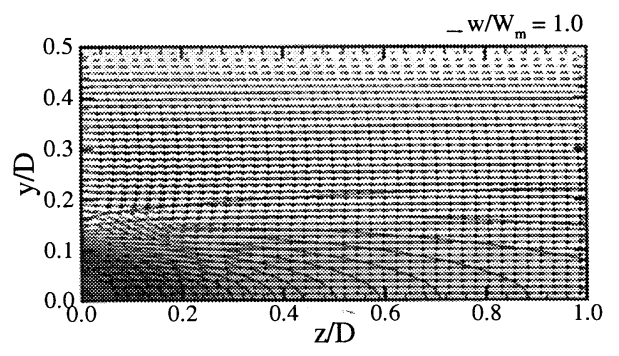

(a) Case-C

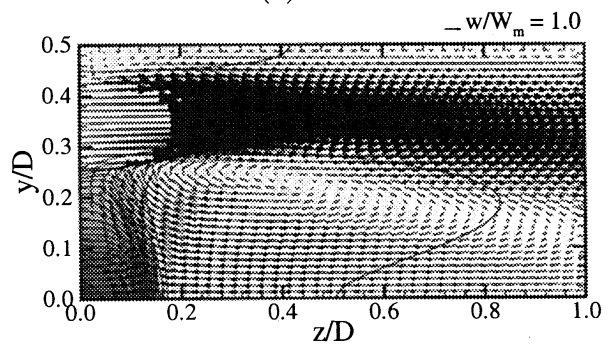

(b) Case-B

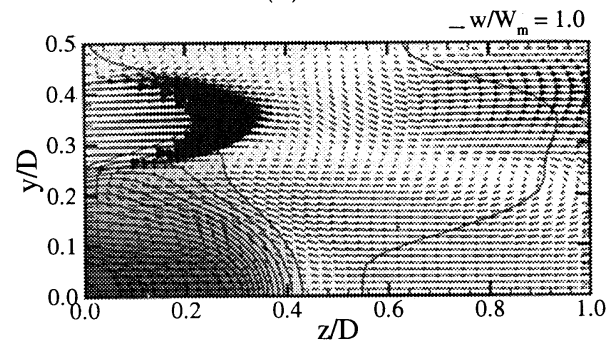

(c) Case-S20

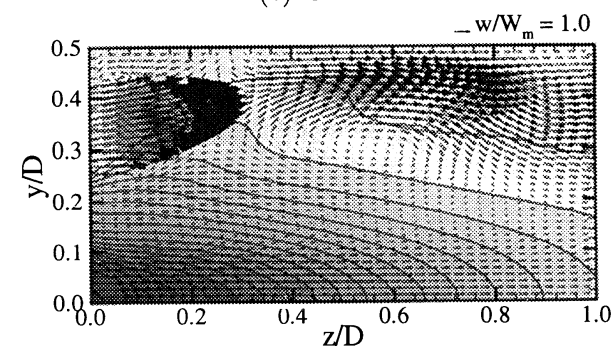

(d) Case-S40

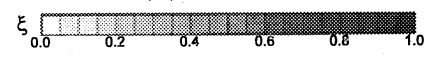

Fig. 8 Magnified views of mixture fraction contours, $\xi$, and velocity vectors at the $y-z$ cross section of $x / D=0$ (cf. Fig.3).

布の非軸対称性は下流域の広い範囲に亘うてその傾向 が持続することが分かる.

つぎに図 9 の (d)〜 (f) に示す旋回を伴う場合につ いて, $S w$ 数を 0.2 に固定して浮力の影響を考察する. 旋回を伴い, かつ浮力が順方向に作用する場合（同図 


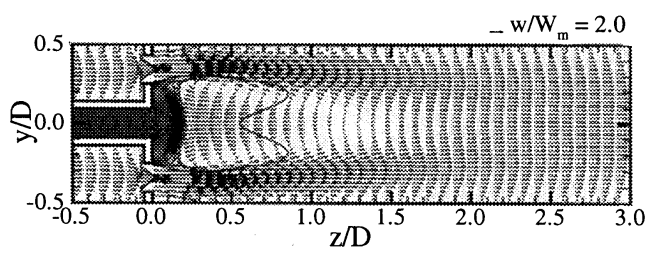

(a) Case-Bb0

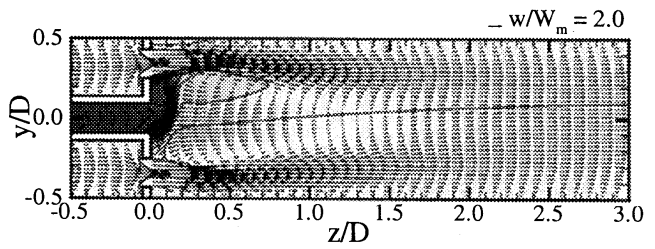

(b) Case-Bb90

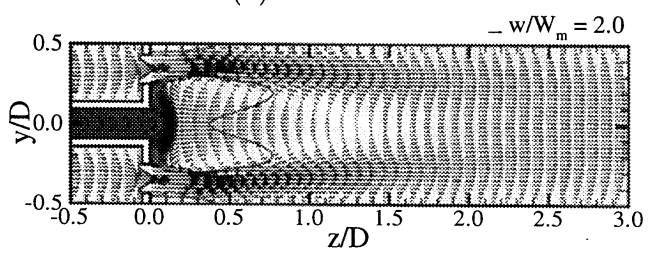

(c) Case-Bb180

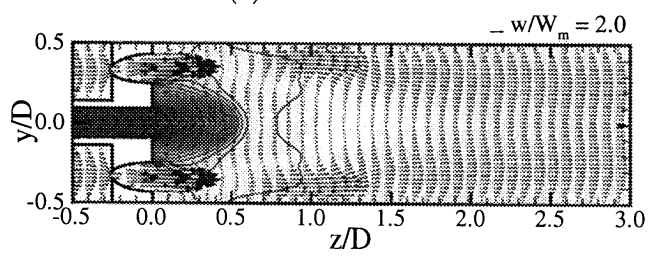

(d) Case-S20b0

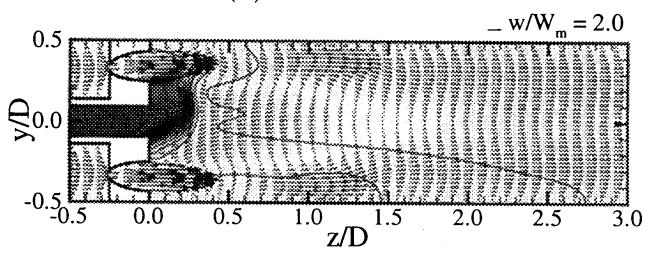

(e) Case-S20b90

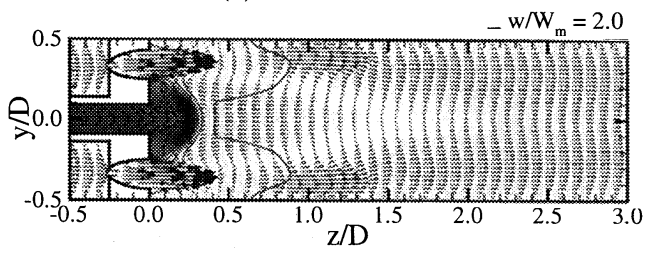

(f) Case-S20b180

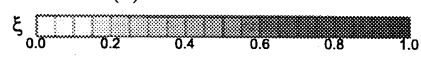

Fig. 9 Mixture fraction contours, $\xi$, and velocity vectors at the $y-z$ cross section of $x / D=0$.

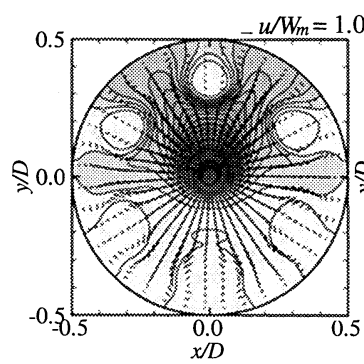

(a) Case-Bb90 (b) Case-S20b90
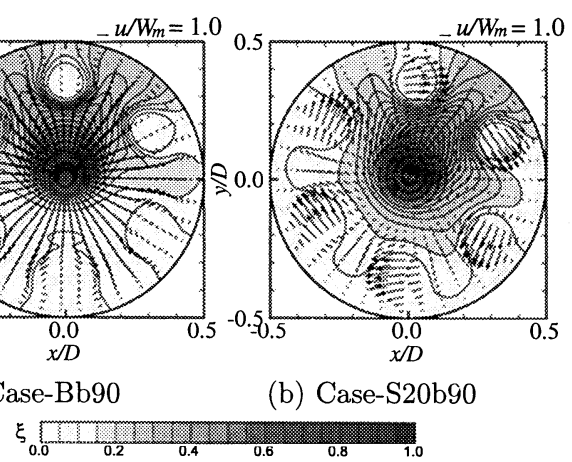

Fig. 10 Mixture fraction contours, $\xi$, and velocity vectors at the $x-y$ cross section of $z / D=$ 0.1 .
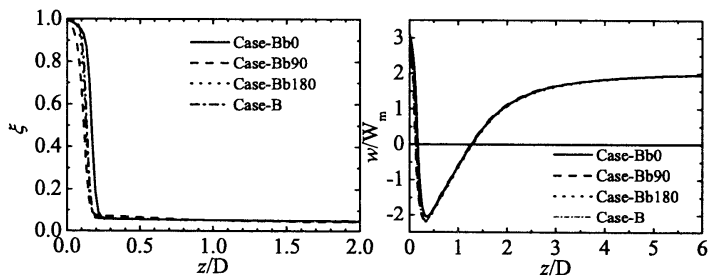

(a) mass fraction, $\xi$

(b) streamwise velocity, $w$ (without swirl)

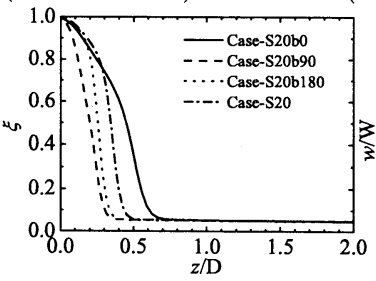

(without swirl)

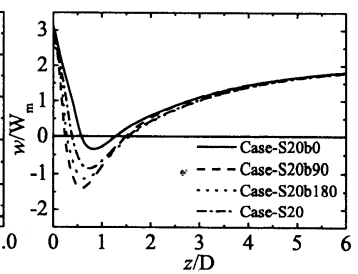

(c) mass fraction, $\xi$ (with swirl)

(d) streamwise velocity, $w$ (with swirl)

Fig. 11 Distributions of mixture fraction, $\xi$, and streamwise velocity, $w$, along the central axis of circular chamber.

(d)）と逆方向に作用する場合（同図 (f)）を比較する と, 後者の混合状態の方が良好であることが分かる. また， $S w$ 数が同じであるにもかかわらず，逆流領域 の規模に違いが見られ, 後者の方が大きな逆流速度を 持つことが分かる.

主流に対して浮力が直交して作用する Case-S20b90 （同図 (e)）の場合には，Case-Bb90 の場合（同図 (b)） と同様, $\xi$ の分布にやはり非軸対称性が見られる. (b) および $(\mathrm{e})$ に対応する横断面分布 $(z / D=0.1)$ をそ れぞれ，図 10 の (a) および (b) に示す。これを見る と, 浮力の作用方向に沿って中心噴流からの流体が管 上方に偏って存在し，旋回のある場合にはさらにその 
流体の占める位置が旋回方向に沿って右斜め上方に大 きく偏ることが確認できる.

図 11 に浮力の作用する条件下において，旋回の有 無による管中心軸上の $\xi$ ならびに $w / W_{m}$ の変化の違 いを示す. なお, いずれの場合に対しても参考のため, 浮力の作用しない場合の結果 (一点鎖線 : Case-B また はCase-S20）を併記した. 同図 (a) および (b) は旋回 の伴わない場合の結果であり，図 9 の (a)〜 (c) に対応 する.これらの図から図 9 のところで述べたとおり, 旋回の伴わない場合には浮力の作用方向に依らず， $\xi$ ならびに $w$ のいずれも類似の変化を示すことが分か る.一方，図 11(c) および (d) に示す旋回の伴う場合 は図 9 の (d)〜 (f) に対応しており, 順方向に浮力が 作用すると図 11(c) の $\xi$ の減少傾向は浮力の作用しな い場合に比して緩慢となり，逆方向に作用する場合に はより短い距離で変化が起こる.また, 図 $11(\mathrm{~d})$ の $w$ についてもその変化を浮力の作用しない場合と比べる と, 浮力が順方向に作用する場合には逆流領域が狭く なり, 逆方向の場合には逆流が強まり，その規模も大 きくなっている.

したがって，浮力の流動・混合特性に与える影響は 旋回を伴う流れ場の方が大きいと判断できる。この理 由として，以下のことが考えられる．旋回が掛かると 管側壁付近に淀み領域が形成され，それが半径方向外 向きへの中心噴流の流れを阻害し，逆流の強さと規模 を小さくすることは前節で述べたとおりであるが，こ の流れのために図は省略するが，中心噴流によって比 較的高温の領域が浮力の作用しない Case-B の場合に 比べて，主流方向の広い範囲に亘って存在する.この ことは図 8(b) および (c) の質量分率 $\xi$ の分布からも 類推できる.このため, 浮力が作用すると旋回のない 場合に比べてその影響を相対的に受け易くなり，逆方 向に浮力が作用すると温度の高い中心噴流が上流側に 押し戻されるような力を受けて減速し，周囲噴流の方 が相対的に大きな速度をとって逆流領域を形成しやす くなる，その一方，順方向の浮力が作用すると逆の現 象が起こって逆流領域が形成されにくくなると考えら れる.なお，浮力の作用が主流と直交する場合には前 述のとおり， $\xi, w$ の分布に見られる非軸対称化のた めに，中心軸上では全体的に $\xi ， w$ の值ともに小さく， 見掛け上，混合が進んだような結果になっている.

\section{5. 結言}

本研究では，管内マルチ噴流に対する旋回成分の付 与ならびに浮力の作用が混合特性に及ぼす影響を数值 的に検討し，以下の結果を得た.
1. 本研究の条件下においては，管内マルチ噴流は旋 回を伴う場合, 混合が抑制される.

2. 管内マルチ噴流はバッフル板下流側端面の近傍に, 管内同軸噴流と比較して混合状態の悪くなる領域 が存在し, 旋回を伴って $S w$ 数が大きくなるほど その領域は下流方向に伸張する.

3. 管内マルチ噴流に及ぼす浮力の影響として, 浮力 の作用方向が主流に平行な場合, その影響はほと んど顕れなかったが, 浮力の作用方向が主流と平 行でない場合には速度および質量分率の分布とも に非軸対称となり，著しく混合が劣化する.

4. 旋回の伴う管内マルチ噴流に浮力が作用する場合, 旋回を伴わない場合には見られなかった特徴とし て, 浮力の作用方向が主流に平行な場合において も流れ場や混合状態が浮力の影響を受けやすい.

\section{謝辞}

本研究の一部は科学技術振興機構 - 戦略的基礎研究 推進事業「資源循環・エネルギーミニマム型システム 技術」研究領域内の「超小型ガスタービン・高度分散 エネルギーシステム」研究の一つとして契約された共 同研究費の補助を受けた。ここに謝意を表する.

\section{文献}

(1) Choi, H.-S., Katsumoto, Y., Nakabe, K. and Suzuki, K., An Experimental Investigation of Mixing and Combustion Characteristics on the Can-Type Micro Combustor with a Multi-Jet Baffle Plate, "Fluid Mechanics and Its Applications -Turbulent, Mixing and Combustion-", 70 (2002), pp. 367-375, Kluwer Academic Publisher.

(2) Woodfield, P. L., Nakabe, K. and Suzuki, K., The Effect of Three-Dimensional Recirculation Flow Structures on Flow Mixir y of Micro-Scaled Confined Jets, "International Journal of Heat and Mass Transfer", 46 (2003), pp.2655-2663.

(3) Tatsumi, K., Woodfield, P. L., Nakabe, K. and Suzuki, K., The Effect of Upstream Flow Conditions to Laminer Mixing in a Miniature Conbustion Chamber, "Proceedings of 4th ASME, JSME Joint Engineering Conference", (2003), CD-Rom (FEDSM2003-45130).

(4) Woodfield, P. L., Nakabe, K. and Suzuki, K., Performance of a Three-Dimentional, PressureBased, Unstructured Finite-Volume Method for LowReynolds-Number Incompressible Flow and Wall Heat Transfer Rate Prediction,, "Numerical Heat Transfer, Part B", Vol. 43, (2003), pp.403-423.

(5) C. M. Rhie and W. L. Chow, Numerical Study of the Turbulent Flow past an Airfoil with Trailing Edge Separation, "AIAA Journal”, Vol. 21,No. 11, (1983), pp.1525-1532.

(6) Becker, H. A., Hottel, H. C. and Williams, G. C., Mixing and Flow in Ducted Turbulent Jets, "Proceedings of 9th Symposium on Combustion", (1983), pp.7-20. 